студентів вищих навчальних закладів, навколо методів, форм та засобів фізичного виховання триває полеміка щодо розширення виховних функцій.

Отже, під час планування навчально-виховного процесу з фізичного виховання слід звернути увагу на науково обгрунтовану методику, не нівелюючи традиційної, тобто багатофункціональну, зумовлену, насамперед, змістом, стратегією і характером способу життя, дотримуючись при цьому дидактичних принципів.

Головна проблема культури здорового способу життя студента полягає в інтелектуальному розвитку, переході від інформаційного навчання до пошуково-творчого, що відповідає вимогам сьогодення, які суспільство висуває до підготовки висококваліфікованого фахівця.

\title{
Література
}

1. Афанасьєв Д. В. Аналіз мотивації студентів щодо здорового способу життя та фізичної активності /Д. В. Афанасьєв, I. В. Городинська // Матеріали V Всеукр. наук.-практ. конф. [Проблеми сучасної валеології, фізичної культури та реабілітації], (Херсон, 7 квітня 2011 р.) / М-во освіти і науки України, Херсонський державний університет. - Херсон, 2011. - С. 192-193. 2. Білоконна Н. I. До проблеми збереження здоров'я студентів вищої педагогічної школи /Н. І. Білоконна, С. П. Білоконний // Матеріали регіон. наук.-практ. конф. [Здоров'я дітей, підлітків, молоді та здоров'язберігаючі технології в освіті], (Кривий Ріг, 6 квітня 2012 р.) / Криворізький педагогічний інститут ДВНЗ «КНУ». - Кривий Ріг, 2012. - С. 30-33. 3. Жеребцов Ю. Здоровый образ жизни и физическая культура студентов Днепропетровского национального университета имени Олеся Гончара (социологические аспекты) / Ю. Жеребцов, О. Татаровський // Матеріали Всеукр. наук.-практ. конф. [Актуальні проблеми фізичного виховання студентів в умовах кредитномодульної системи навчання], (Дніпропетровськ, 12-13 квітня 2012 р.) / Дніпропетровський національний університет ім. О. Гончара. - Дніпропетровськ, 2012. - C. 78-82. 4. Лапіна К. М. Фізична активність - ознака здорового способу життя / К. М. Лапіна, Ю. А. Харченко, М. М. Твердохліб // Сучасні проблеми фізичного виховання і спорту школярів та студентів України. - Суми, 2007. - С. 257-261. 5. Павленко Е. Е. Здоровый образ жизни студенческой молодежи / Е. Е. Павленко // Матеріали I Всеукр. наук.-метод. конф. [Актуальні проблеми формування здорового способу життя студентської молоді методами фізичної культури], (Харків, 19 жовтня 2011 р.) / М-во освіти і науки України, Харківський національний автомобільнодорожній університет. - Харків, 2011. - С. 21-25. б. Ткачук О. Г. Медико-біологічні проблеми здорового способу життя студентської молоді / О. Г. Ткачук, О. М. Бойко // Матеріали I Всеукр. наук.-метод. конф. [Актуальні проблеми формування здорового способу життя студентської молоді методами фізичної культури], (Харків, 19 жовтня 2011 р.) / М-во освіти і науки України, Харківський національний автомобільно-дорожній університет. - Харків, 2011. - С. 47-50.

УДК 378. 147

С. П. Білоконний,

кандидат педагогічних наук, ст. викладач,

Криворізький педагогічний інститут

ДВНЗ «Криворізький національний університет»

\section{ВИКОРИСТАННЯ МЕТОДУ ПРОЕКТІВ В ЕКОЛОГІЧНІЙ ПІДГОТОВЦІ МАЙБУТНІХ ФАХІВЦІВ ДОШКІЛЬНОЇ ОСВІТИ}

Білоконний С. П. Використання методу проектів в екологічній підготовці майбутніх фахівців дошкільної освіти.

Статтю присвячено проблемі професійно-екологічної підготовки фахівців дошкільного виховання. Метод проектів розглядається як один із засобів виховання екологічної культури майбутніх педагогів.

Ключові слова: метод проектів, екологічне виховання, дошкільна освіта.

Билоконный С. П. Использование метода проектов в экологической подготовке будущих специалистов дошкольного образования.

Статья посвящена проблеме профессионально-экологической подготовки специалистов дошкольного воспитания. Метод проектов рассматривается как средство воспитания экологической культуры будущих педагогов. 
Ключевые слова: метод проектов, экологическое воспитание, дошкольное образование.

Bilokonniy S. P. Using project method in environmental preparing future professionals preschool education.

The article is devoted to the problem of professional-ekological training of specialists of preschool education. The method of projects to be one of the means of future teacher.

Key words: method of projects, ecological education, future teacher.

Початок XXI століття людство зустрічає безпрецедентним завданням шкоди навколишньому середовищу, загрозливим посиленням глобальної екологічної кризи, що пов'язано 3 особливостями соціально-економічного розвитку у XX столітті, зорієнтованого переважно на швидкі темпи економічного зростання. Щоб зупинити цю кризу, необхідно оптимізувати взаємодію людського суспільства (соціальної підсистеми) 3 природним середовищем (екологічною підсистемою). Виникла потреба у зміні філософії життя, тотальній екологічній грамотності нового суспільства, що відрізняється величезними темпами науково-технічного процесу.

Професійна компетентність фахівців дошкільної освіти - це теоретична і практична підготовка до здійснення діяльності, пов'язаної 3 розвитком особистості дітей дошкільного віку. Професійно-екологічна компетентність $є$ важливим складником загальної професійної компетенції в тій частині, яка стосується педагогічного супроводу 3 метою надання допомоги дітям у гармонізації стосунків 3 природним довкіллям, вихованням екокультурної особистості дошкільника.

Щоб підготувати вихователя-професіонала, теоретичних знань замало. Треба навчити студента професійно мислити і діяти. На думку багатьох науковців (Н. Бібік, О. Біда, Г. Бєлєнька, В. Бондар, І. Зязюн, О. Матвієнко та інші), професіоналізму не досягти без активності, творчості, ініціативності, прагнення до пізнання нового.

Meта статmі полягає в пошуку шляхів удосконалення якості професійно-екологічної підготовки майбутніх фахівців дошкільної освіти.

В екологічній підготовці майбутнього вихователя особливого значення набуває формування потреби в постійному самовдосконаленні й самоосвіті, оскільки, по-перше, ознайомлення дітей з природою здійснюється за краєзнавчим принципом і передбачає побудову педагогічного процесу з урахуванням місцевих природних особливостей, із якими повинен ознайомитися вихователь й адаптувати свою професійну діяльність до умов конкретного регіону; по-друге, вихователь повинен бути обізнаним із сучасними науковими доробками, новим педагогічним досвідом, які б спонукали до власного творчого пошуку.

Вихователь дошкільного закладу є носієм екологічної культури для дітей, тому він повинен добре знати сучасні екологічні проблеми, сповідувати еколого-гуманістичну модель виховання, мати розвинену потребу у спілкуванні з природою, володіти технологіями екологічної освіти дошкільників.

Формування екологічної культури - це виховання такого ставлення до природи, яке перетворює знання про світ природи, необхідність дбайливого ставлення до природи та іiі охорони на керівництво до дії, мотив поведінки.

Наші спостереження свідчать про те, що розв'язувати завдання формування екологічно мотивованої поведінки дітей дошкільного віку може лише людина, яка сама має екологічно спрямовані потреби, інтереси, ідеали.

Сучасні науковці (О. Любарська, А. Кіктенко, В. Маршицька, О. Пехота та інші) наголошують на тому, що підвищити ефективність екологічної підготовки майбутніх вихователів допомагають методи активного навчання. Універсальним засобом впливу на інтелектуальну, емоційно-чуттєву, вольову сферу особистості, розвиток їі ініціативності, творчості є метод проектів. Цей метод, підкреслює Н. Горопаха, має практичну цільову дію та надає широкі можливості для актуалізації набутих знань, самореалізації. 
Метод проектів був започаткований американським філософом і педагогом Дж. Дьюї. Його послідовник В. Кілпатрик удосконалив систему роботи над проектами, розробив їх класифікацію. У 20-ті роки XX ст. С. Шацький став ініціатором активного запровадження методу проектів у практику викладання. Серед прихильників цього методу можна назвати С. Кагарова, М. Крупєніну, В. Шульгіна; сучасні дослідження - Є. Полат, В. Маршицька, Г. Бєлєнька.

У педагогічному процесі вищого навчального закладу можуть використовуватись досліднищькі, творчі, ігрові, інформащійні, практико-орієнтовані проекти. Курс «Основи природознавства $з$ методикою ознайомлення дітей з природою», на наш погляд, найбільш сприятливий для використання різних типів проектів. Зміст та форми роботи розглянемо детальніше.

Перше залучення майбутніх вихователів до проектної діяльності буде доцільним під час вивчення теми «Природа України». Студентам можна запропонувати виконати творчу роботу з теми «Особливості Дніпропетровського природно-територіального комплексу»:

- Природні умови Дніпропетровського регіону (рельєф, клімат, води, грунти). Особливості ознайомлення з ними дітей дошкільного віку.

- Рослинний та тваринний світ Дніпропетровщини. Ознайомлення з ним дітей.

- Екологічні проблеми регіону. Особливості екологічного виховання дітей.

Роботу над проектом необхідно почати з визначення його теми і мети. Потім розробляємо план діяльності для досягнення поставленої мети, тобто зміст проекту, та критерії оцінки результату.

Наступний етап - виконання проекту: збір інформації (спостереження, робота 3 літературою, анкетування), аналіз інформації і формулювання висновків.

Завершується виконання проекту презентацією результатів, підбиттям підсумків (рефлексією).

Ми поділяємо думку Г. Бєлєнької про те, що ефективність та результативність проектів зумовлена дотриманням таких педагогічних умов: позитивна мотивація для особистісної установки студента на участь у проекті; варіативність і гнучкість змісту проекту, який ураховує індивідуальні особливості студентів і рівень їхньої підготовки; повага до особистості студента і його вибору; комплексна організація освітньої діяльності студентів під час виконання проекту (навчально-пізнавальна, навчально-практична, самостійна, аудиторна та ін.) [1, с. 58].

Наведемо приклади проектів екологічного змісту.

Проект на тему «Магія кімнатних рослин».

Мета: розширити уявлення майбутніх вихователів про світ кімнатних рослин, можливості їх розведення, використання в оформленні приміщення дошкільного закладу і домівки 3 урахуванням біологічних особливостей; ознайомити 3 особливостями використання методу екологічних проектів; розвивати самостійність, вияви творчості, прагнення досягати мети.

План проведення:

1. Виставка кімнатних рослин, які виростили студенти, викладачі, співробітники факультету. Для кожного експонату виставки виготовляється табличка 3 назвою рослини та коротким довідковим матеріалом.

2. Екскурсія-огляд «Маленькі таємниці кімнатних мандрівників». У репрезентації рослин є доцільним використання групи студентів-екскурсоводів, кожен з них розповідає про свої улюблені кімнатні рослини (наприклад, фіалку, аспарагус, кактус, алое, каланхое тощо) за таким орієнтовним планом: назва, родина, походження, зовнішній вигляд характеристика листка, квітки; умови вирощування, способи розмноження, цікаві відомості.

3. Розповідь «Рослини в інтер'єрі сучасної людини».

4. Виставка літератури 3 кімнатного квітникарства (стенди 3 довідковою та методичною літературою, періодичними виданнями). 
5. Фото-звіт «Рослини в моєму домі».

6. Виставка-продаж посадкового матеріалу. Продавець-консультант з числа студентів, які мають досвід домашнього квітникарства (пропонуються поради щодо догляду за тією чи іншою рослиною).

7. «Флористичні мотиви дівочої краси» - демонстрація дівочого вбрання 3 використанням флористичних мотивів.

Проект на тему «Ділянка ДНЗ - квітучий сад»

Мета: розширити знання майбутніх фахівців про рослини (декоративні, плодові, ягідні дерева та кущі, трав'янисті рослини), які можна використовувати для озеленення ділянки ДНЗ; спонукати до активної участі в озелененні ділянки ДНЗ; розвивати самостійність, творчість; виховувати розуміння практичної спрямованості й корисності проектної технології.

База проведення: дошкільний навчальний заклад.

План проведення:

1. Аналіз озеленення ділянки обраного ДНЗ. Здійснюється підгрупами студентів, які аналізують ділянки різних вікових груп.

2. Розроблення і презентація схем-рекомендацій з удосконалення озеленення ділянок ДНЗ; колективне обговорення та вибір найкращого варіанту.

Практична діяльність з озеленення ділянки ДНЗ (зміст міні-проектів обирається згідно iз здійсненим аналізом й обраним варіантом проекту). Наприклад: ділянка дітей молодшого дошкільного віку - міні-проект «Подарунок малюкам» передбачає облаштування клумби на місці стихійно виниклої доріжки через трав'янисту ділянку; ділянка дітей середнього дошкільного віку - міні-проект «Яблунька» спрямований на посадку плодового дерева; ділянка дітей старшого дошкільного віку - міні-проект «Посадимо дерево» потребує спільної діяльності всіх учасників проекту та вихованців старшої вікової групи.

3. Екскурсія екологічною стежиною «У світі рослин».

Критерії оцінювання успішності проектів були такими:

а) мета проекту, її зв'язок із майбутньою діяльністю вихователя дошкільного закладу;

б) структура проекту, логічність поєднання частин;

в) виконання основних вимог методу проектів: добровільність та щиросердність участі у проекті, активність і можливість творчих виявів кожного з учасників, поступовість крокування до результату, завершеність проекту яскравою подією, вплив проекту на покращення якості життя всіх учасників проекту;

г) можливість використання проекту в роботі з дітьми дошкільного віку, вихователями, батьками;

д) оцінка та пропозиції.

Отже, досвід використання різних видів екологічних проектів засвідчує, що за такої діяльності в майбутніх вихователів підвищується рівень активності та самостійності, формується екологічна культура, зростає екологічна свідомість, виникає стійка потреба допомагати природі й захищати іiі.

\section{Література}

1. Бєлєнька Г. В. Інтерактивні прийоми викладання навчальної дисципліни у вищій школі / Г. В. Бєлєнька. - К., 2003. - 118 с. 2. Горопаха Н. Реалізація принципів розвивального навчання в екологічній освіті дошкільнят / Н. Горопаха // Оновлення змісту, форм та методів навчання і виховання в закладах освіти: [зб. наукових праць]. - Рівне, 2002. - Вип.19. - С. 58-64. 3. Маршицька В. Екологічні проекти / В. Маршицька // Дошкільне виховання. - 2001. - № 5. - С. 24-25. 